https://doi.org/10.31426/ijamsr.2018.1.9.912

International Journal of

\title{
THE EFFECT OF DEVELOPING TEST-WISENESS ON IRANIAN EFL LEARNERS'LISTENING COMPREHENSION AND TEST ANXIETY
}

\author{
Iraj Pazooki ${ }^{1}$, Aris Hakhverdian', Masoud Yazdani Moghadam ${ }^{3}$, Roshanak Daraei ${ }^{4}$
}

English Language Teaching Department, Islamic Azad University, Garmsar, Iran

englishtutor2017@gmail.com

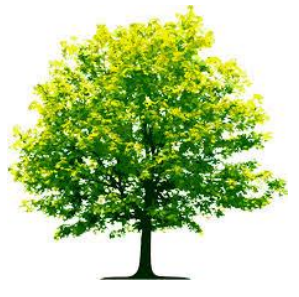

Keywords: Test wises, Listening comprehension, Test anxiety

\begin{abstract}
A B S T RA C T
This study was an attempt to investigate the effect of developing test-wiseness on Iranian EFL learners' listening comprehension and test anxiety. 50 intermediate male EFL learners out of 90 were selected to participate in this study by administrating an OPT, and they were non-randomly assigned into two groups, experimental control groups. As pretest, both groups were given listening sections of the different Preliminary English Test (PET) to measure the participants' listening comprehension at the beginning of the research period. Foreign Language Classroom Anxiety Scale (FLCAS) was administrated to measure the learners' anxiety toward listening comprehension during treatment sessions. During the treatment, both groups were taught to listen section of New Interchange 1; English for international communication-an English course book written by Jack $C$. Richards. The experimental group was instructed on test wises strategies while working on the listening materials. After treatment, both groups were given listening section of another PET as posttest. Data were analyzed through analysis of covariance (ANCOVA) and t-test to compare the mean of the pretest and posttest of both groups. The finding revealed that promoting learners' test wises in the experimental group significantly affected listening comprehension of the EFL learners. Moreover, it was found the post-treatment anxiety of the learners in the two groups were not significantly different, suggesting that instructing test wises strategies may not reduce learners' anxiety.
\end{abstract}

Citation: Iraj Pazooki, Aris Hakhverdian, Masoud Yazdani Moghadam, Roshanak Daraei (2018). The Effect Of Developing Test-Wiseness On Iranian Efl Learners 'listening Comprehension And Test Anxiety. International Journal of Advanced Multidisciplinary Scientific Research (IJAMSR) ISSN:2581-4281 Vol 1, Issue 9, November, 2018, \#Art.912, pp 10-20 


\section{International Journal of Advanced Multidisciplinary Scientific Research (IJAMSR) ISSN:2581-4281}

\section{Introduction}

English as an international language is very important for human life because people from different nations can communicate with each other through the language. On the other hand testing is an indispensable element of English language teaching; so, test wises as an important aspect of testing should be taken into consideration. Test wises (TW) has been defined as the ability to respond advantageously to an item containing extraneous clues and to obtain credit without knowledge of the subject matter being tested. Test wises are a source of invalidity since it allows some test takers have an unfair advantage over others (Allan, 1992). Test wises strategies (TWS) can be used by test takers in responding to test tasks. TW is important because it is not equally benefited by test takers at different ability levels (Cohen, 1998; Chance, 1992). If the test takers possess both materials being tested and TW knowledge, their score can be greater than the score of test takers who know little about TW. One should be careful to interpret the meaning of test score since it can be influenced by TW because it can result in a potential validity problem (Rogers \& Bateson 1991). Research on TW indicates EFL learners become more relaxed, more confident, and more enthusiastic about taking tests (Vattanapath\&Jaiprayoon, 1990). TW is a valuable source of content or construct invalidity since it examines students' ability to answer correctly by exploiting weakness in test design. It is a relatively new undertaking to use data on test taking strategies in order to validate language tests (Cohen, 1998, p. 217).
During the history of teaching English as a foreign or second language, the listening has long been neglected skill (Brown, 2007; Chastain, 1998). Listening is the most important skill in helping language learners to speak and can be defined as the process of understanding speech in a first or second language. The study of listening comprehension processes in second language learning focuses on the role of individual linguistic units (e.g. phonemes, words, grammatical structures) as well as the role of the listeners' expectations, the context, and background knowledge topics(Richards \& Schmidt, 2010. P. 344). Listening is a receptive skill, and receptive skills(i.e. listening and reading) are clearly the more enigmatic of the modes of performance. Language learners cannot observe the actual act of listening or reading. They observe while they are listening or reading, therefore all assessments of receptive performance must be inferred. On the other hand, you are observing the result of the listening. Anxiety is one of the most negatively influential variables, which prevents learners from learning successfully which may contribute to poor aural and oral performance. Anxiety is a complex affective concept associated with feelings of frustration, uneasiness, self-doubt, apprehension or worry (Scovel, 1978, p. 134). Three components of foreign language anxiety have been identified and examined, namely communication apprehension, test anxiety and fear of negative evaluation. Test anxiety (TA) is apprehension over academic evaluation. TA may be generated to be deficits in students' learning and study skill, or it could be caused by students' poor performance in the past. Chastain (1998) examined the correlation between ability and affective factors, including test anxiety and foreign language learners' course grades. The importance oral skill in language learning in our country where English is taught as a 


\section{International Journal of Advanced Multidisciplinary Scientific Research (IJAMSR) ISSN:2581-4281}

foreign language should be taken into consideration because Iranian EFL learners have few opportunities to talk with English native speakers. In order to improve the EFL learners' speaking skill, the researcher has worked on listening. The main purpose of the present study is to investigate the effect of developing TW on male Iranian intermediate EFL learners' listening comprehension and test anxiety.

\section{Related Studies}

Regarding the research studies on investigating the effects of test-wiseness on different parts of L2 learning/ teaching in general and listening comprehension performance in particular, a few studies have been conducted. For instance, Mousavi, Arizavi, and Namdari (2014) conducted a research study on investigating to see whether preparation influences the learners' reading comprehension of IELTS and TOEFL? In other words, this study tried to find answer(s) to the following question: Does getting a high score imply enhancement in the reading comprehension ability? In order to conduct the research, sixty EFL learners were selected to take part in a preparation program in which they were instructed different techniques and strategies to deal with the reading section of TOEFL and IELTS tests. The obtained results revealed that "there was a significant effect of IELTS reading preparation on test performance, while there was no such effect for the TOEFL reading preparation program " (p. 18). That is to say, the preparation effect was more visible on the performance of the IELTS reading test than on that of the TOEFL reading test. The IELTS preparation group significantly outperformed the TOEFL preparation group on the IELTS reading test. In contrast, the TOEFL preparation group performed better than the IELTS preparation group on the TOEFL reading test, but this difference was not significant. These different effects of test preparation on test performance are clarified in the current study findings.

Tsuchihira (2008) tried to explore the Relationships between Test-Wiseness and the English Listening Test Scores. He concluded that the listening test score data in the present study did not form a normal distribution at first. Though the data was normalized in order to execute the correlation analysis, it is desirable to have normaldistributed data from the first. With a bigger sample size, it will be possible. Though I do not yet have a definite idea on how we should consider the problem of construct validity related to the problem of test-wiseness, the results of the present study clearly have some suggestions on our item writing.

Yang (2000) attempted to investigate the influence of test-wiseness upon performance on the Test of English as a Foreign Language (TOEFL). In order to achieve this objective, a sample of 390 Chinese TOEFL candidates was selected and asked to respond with a modified version of the Test of Test-wises (TTW) and the TOEFL Practice Test B (ETS, 1995d). The results of the thinkaloud protocol analysis showed that test-wise students higher performance on the susceptible items may be explained by the "construct-irrelevant easiness" (Messick, 1989) achieved through the combination of test-wise susceptible items, the possession of testwiseness skills, and partial knowledge. If the ability to apply test-wiseness strategies combined with partial knowledge is considered irrelevant to the construct measured by the TOEFL, it is suggested that the current administration procedures and the format of the TOEFL need to be reviewed and improved. 


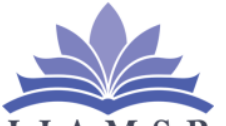

I J A M S R

\section{International Journal of Advanced Multidisciplinary Scientific Research (IJAMSR) ISSN:2581-4281}

Bachman (2000) reported that test preparation did not produce a significant gain in test scores. Similarly, Celestine and Ming (1999) found that IELTS preparation did not make a significant difference in the scores of either average or high proficiency students from different disciplines. They went further by explaining that a preparation course did not have any effect on the test scores because "IELTS is a test of proficiency thus the knowledge of test-taking strategies cannot substitute for fluency" (p. 46).

Another study referring to the effect of IELTS preparation on test performance in Asian students was carried out by Hayes and Read (2004). The findings revealed that though approximately half of the student population improved their scores, the difference was not significant.

An earlier study by Hayes and Watt (1998) also focused on the effect of the IELTS test preparation on the test performance of Asian students. They found that a twomonth program with a testing rather than a teaching focus did not improve students' performance.

A similar finding was reported by Elder and O'Loughlin (2003) in their study of IELTS score gains of 112 students after a three-month intensive English study in either Australian or New Zealand. Although the average score gain of these students was half a band overall with a slightly greater average improvement for listening, there was no advantage for the subset of students who had taken a course focusing specifically on test preparation. In a more recent study, Sheshkelani, Ahari and Aidinlou (2012) found that Iranian English major students without test preparation got lower scores in listening than those who were prepared for TOEFL.

Based on the findings of the related studies in the field of study, test-wiseness has proved to be useful in developing different language skills especially, listening and cause to reduce anxiety when the test-takers are assessed by teacher. Test-wises is a skill that helps learners choose the correct alternative on objective tests when learners are not sure of the answer. If test-takers possess both materials being tested and test-wiseness knowledge, their scores can be greater than the scores of test-takers who know little about the test - wiseness. One should be careful to interpret the meaning of test scores if the score can be influenced by test- wiseness because it can result a potential validity problem (Rogers \& Bateson, 1991).

The importance oral skills in language learning in our country where English is taught as a foreign language should be taken into consideration because Iranian EFL learners have few opportunities to talk with English native speakers. Accordingly, in order to improve the EFL learners' spoken skills, the researcher worked on listening as the most important skills in English. In the present study, the main purpose was to investigate the effect of developing test-wiseness on male Iranian intermediate EFL learners' listening test and test anxiety. In order to achieve the purpose, the following research questions were formulated: 


\section{International Journal of Advanced Multidisciplinary Scientific Research (IJAMSR) ISSN:2581-4281}

1. Does developing test wises have any statistically significant effect on the listening comprehension of male Iranian intermediate EFL Learners?

2. Does developing test wises have any significant effect on the test anxiety of male Iranian intermediate EFL Learners?

\section{METHODOLOGY}

\section{Design}

This study was conducted in order to find out the effect of developing test-wiseness on the Iranian EFL learners' listening test performance and test anxiety. In other words, this study sought to investigate the effect of developing test-wiseness (i.e., independent variable) on the Iranian EFL learners' listening test performance and test anxiety (i.e., dependent variables) via a pretest and a posttest; hence, it was an experimental research.

\section{Participants}

A total of 50 intermediate male students within the age of 16 to 24, studying at an English language Institute in Iran participated in this study. They were all from Pakdasht, a city in Tehran province in Iran. The language learners took the homogeneity test (OPT) and they were divided into two different groups, an experimental group and a control group, each containing 25 participants whose first language was Persian. Moreover, the sample was not random.

\section{Instruments}

OPT

OPT consisted 60 questions in two parts: part one with the first 40 questions, and part two with 20 items. The OPT was used before the main administration. The reliability of the test was estimated to be 0.792 , after being given to 15 respondents similar in characteristics to the target objects, which can be regarded as a reasonable degree of reliability.

\section{Listening Pretest}

In order to evaluate the listening comprehension ability of the learners before treatment, the two groups were given a pretest. This test was the listening part of a PET Practice Test; five tests for Cambridge English Preliminary by Jenny Quintana. The listening paper had four parts comprising 25 questions. The learners were expected to understand a range of spoken materials, in both informal and neutral setting on range of everyday topics. The reliability of the test was estimated to be 0.801 .

\section{FLCAS}

For measuring learners' anxiety toward listening comprehension before and after treatment, the test anxiety questionnaire containing 33 items was given to the participants. The scale consisted of 33 Likert-style questions with point ranging strongly agree, agree, no idea, disagree to strongly disagree. This test, called FLCAS (Foreign Language Classroom Anxiety Scale), was adapted from Horwitz, Horwitz and Cope (1986). The reliability of the questionnaire was estimated to be 0.711 . 


\section{International Journal of Advanced Multidisciplinary Scientific Research (IJAMSR) ISSN:2581-4281}

\section{Listening Posttest}

After treatment, to measure the listening comprehension ability of the learners a posttest, similar to the pretest, was administered. The reliability of the test was estimated to be 0.781 .

\section{Procedure}

Having administrated OPT, 50 EFL learners were selected to take part in the study as the members of two experimental groups (an experimental and a control groups). Then, the participants were given the listening pretest. Likewise, the test anxiety questionnaire was administered to measure the learners' anxiety toward listening comprehension before the treatment. The instruction for both groups took place in 8 sessions and each session lasted 60 minutes. The experimental group revised test wises strategies (TWS) instruction in the listening part of the teaching materials. Water and Siebert (1990); Wenden, 1991 taxonomy of TWS is a widely used taxonomy in the general education literature which classifies TWS into three major categories: 1strategies used before answering test, 2- strategies used during answering test, 3- strategies used after answering the test. The learners in the control group were provided with the usual lessons of listening parts of the teaching materials (there was no developing TWS). Having finished the treatment, the two groups took part in a listening posttest.

\section{RESULTS}

\section{Answering Research Question 1}

Table 1:Adjusted Posttest Listening Means for
Experimental and Control Groups

\begin{tabular}{|c|c|c|c|c|}
\hline \multirow{2}{*}{ Group } & & & \multicolumn{2}{|c|}{$\begin{array}{c} \\
\text { Mean Confidence } \\
\text { Interval }\end{array}$} \\
\cline { 3 - 5 } & & $\begin{array}{c}\text { Std. } \\
\text { Error }\end{array}$ & $\begin{array}{c}\text { Lower } \\
\text { Bound }\end{array}$ & $\begin{array}{c}\text { Upper } \\
\text { Bound }\end{array}$ \\
\hline Experimental & $10.413^{\mathrm{a}}$ & .328 & 9.753 & 11.073 \\
\hline Control & $8.107^{\mathrm{a}}$ & .328 & 7.447 & 8.767 \\
\hline
\end{tabular}

Tables 1 present the adjusted posttest mean scores for two groups. As can be seen, the adjustment for the experimental $(M=10.41)$ is higher than that of the control group $(M=8.10)$. This implies that developing TW was effective in promoting the listening comprehension of the learners.

Table 2: ANCOVA Results for Experimental and Control Groups on Listening Scores

\begin{tabular}{|c|c|c|c|c|c|c|}
\hline Source & $\begin{array}{l}\text { Type III } \\
\text { Sum of } \\
\text { Squares } \\
\end{array}$ & $\mathrm{df}$ & $\begin{array}{l}\text { Mean } \\
\text { Square }\end{array}$ & $\mathrm{F}$ & Sig. & $\begin{array}{c}\text { Partial } \\
\text { Eta } \\
\text { Squared } \\
\end{array}$ \\
\hline $\begin{array}{c}\text { Corrected } \\
\text { Model }\end{array}$ & $268.173^{\mathrm{a}}$ & 2 & 134.086 & 50.237 & .000 & .681 \\
\hline Intercept & 126.758 & 1 & 126.758 & 47.491 & .000 & .503 \\
\hline $\begin{array}{c}\text { Listening } \\
\text { Pretest }\end{array}$ & 172.953 & 1 & 172.953 & 64.798 & .000 & .580 \\
\hline Group & 65.462 & 1 & 65.462 & 24.526 & .000 & .343 \\
\hline Error & 125.447 & 47 & 2.669 & & & \\
\hline Total & 4681.000 & 50 & & & & \\
\hline $\begin{array}{c}\text { Corrected } \\
\text { Total }\end{array}$ & 393.620 & 49 & & & & \\
\hline
\end{tabular}




\section{International Journal of Advanced Multidisciplinary Scientific Research (IJAMSR) ISSN:2581-4281}

The ANCOVA value, $\mathrm{F}=24.52, \mathrm{P}=0.00$, indicated the difference was statistically significant. As a result, the hypothesis to the first research question was rejected. The Eta Squared value of 0.343 showed that about 34\% of the variability can be attributed to the effect of treatment. As displayed in table 2, the two groups were also significantly different $(\mathrm{F}=64.79, \mathrm{P}=0.00)$ at present phase, however, the employment of the ANCOVA procedure cancelled out the initial difference.

With the aim of triangulating data analysis, the data were also examined for within-group variability. For this purpose, the prettiest of both experimental and control groups were compared with their respective posters, scores to see if there was any significant improvement from pretest to posttest. The results are presented in Table 3 and Table 4.

Table 3: Pretest and Posttest Listening Mean Scores for both Groups

\begin{tabular}{|l|c|c|c|c|c|}
\hline \multicolumn{2}{|c|}{} & & & \multicolumn{1}{c|}{$\begin{array}{c}\text { Std. } \\
\text { Mean }\end{array}$} & $\begin{array}{c}\text { Error } \\
\text { Nean }\end{array}$ \\
\hline \multirow{2}{*}{$\begin{array}{l}\text { Pair } \\
1\end{array}$} & $\begin{array}{c}\text { Listening } \\
\text { Ex Pre }\end{array}$ & 7.1200 & 25 & 3.01828 & .60366 \\
\cline { 2 - 6 } & $\begin{array}{c}\text { Listening } \\
\text { Ex Post }\end{array}$ & 10.6400 & 25 & 2.95635 & .59127 \\
\hline \multirow{2}{*}{$\begin{array}{l}\text { Pair } \\
2\end{array}$} & $\begin{array}{c}\text { Listening } \\
\text { Con Pre }\end{array}$ & 6.4800 & 25 & 2.27523 & .45505 \\
\cline { 2 - 6 } & $\begin{array}{c}\text { Listening } \\
\text { Con Post }\end{array}$ & 7.8800 & 25 & 1.92180 & .38436 \\
\hline
\end{tabular}

Table 4: Paired T-Tests Results Comparing Pretest and Posttest Listening Mean Scores in both Groups

\begin{tabular}{|c|c|c|c|c|c|c|c|c|c|}
\hline & \multicolumn{5}{|c|}{ Paired Differences } & \multirow[b]{3}{*}{$\mathrm{T}$} & & \multirow{3}{*}{\begin{tabular}{|} 
Sig. \\
$(2-$ \\
taile \\
d)
\end{tabular}} \\
\hline & & \multirow[b]{2}{*}{$\begin{array}{l}\mathrm{Me} \\
\text { an }\end{array}$} & \multirow{2}{*}{$\begin{array}{c}\text { Std. } \\
\text { Deviat } \\
\text { ion }\end{array}$} & \multirow{2}{*}{\begin{tabular}{|c} 
Std. \\
Erro \\
$r$ \\
Mea \\
$n$ \\
\end{tabular}} & \multicolumn{2}{|c|}{$\begin{array}{c}95 \% \\
\text { Confidence } \\
\text { Interval of } \\
\text { the } \\
\text { Difference }\end{array}$} & & & \\
\hline & & & & & \begin{tabular}{|c} 
Low \\
er
\end{tabular} & $\begin{array}{c}\text { Uppe } \\
\text { r }\end{array}$ & & $\mathrm{f}$ & \\
\hline $\begin{array}{l}\mathrm{Pa} \\
\text { ir } \\
1\end{array}$ & $\begin{array}{l}\text { Listen } \\
\text { ing Ex } \\
\text { Pre - } \\
\text { Listen } \\
\text { ing Ex } \\
\text { Post }\end{array}$ & $\begin{array}{r}3.5 \\
20\end{array}$ & $\begin{array}{r}1.7587 \\
9\end{array}$ & $\begin{array}{r}.351 \\
76\end{array}$ & $\begin{array}{r}4.245 \\
99\end{array}$ & $\begin{array}{r}2.794 \\
01\end{array}$ & $\begin{array}{r}- \\
10 . \\
00\end{array}$ & $\begin{array}{l}2 \\
4\end{array}$ & $\begin{array}{r}.00 \\
0\end{array}$ \\
\hline $\begin{array}{l}\mathrm{Pa} \\
\text { ir } \\
2\end{array}$ & $\begin{array}{l}\text { Listen } \\
\text { ing } \\
\text { ContP } \\
\text { re - } \\
\text { Listen } \\
\text { ing } \\
\text { Cont } \\
\text { Post }\end{array}$ & $\begin{array}{r}1.4 \\
00\end{array}$ & $\begin{array}{r}1.8257 \\
4\end{array}$ & $\begin{array}{r}.365 \\
15\end{array}$ & $\begin{array}{r}2.153 \\
63\end{array}$ & $\begin{array}{r}.6463 \\
7\end{array}$ & $\begin{array}{r}3.8 \\
3\end{array}$ & 4 & $\begin{array}{r}.00 \\
1\end{array}$ \\
\hline
\end{tabular}

As can be seen, in both experimental $\left(\mathrm{t}_{(24)}=10.00, \mathrm{p}=\right.$ $0.00)$ and control $\left(\mathrm{t}_{(24)}=3.83, \mathrm{p}=0.00\right)$ groups, the listening comprehension improved from pretest to posttest; however, this improvement was much higher in the experimental group, exhibited in the t-value (10.00).

\section{Answering Research Question 2}




\section{International Journal of Advanced Multidisciplinary Scientific Research (IJAMSR) ISSN:2581-4281}

Table 5: Adjusted Posttest Anxiety Means for Experimental and Control Groups.

\begin{tabular}{|c|c|c|c|c|}
\hline \multirow[b]{2}{*}{ Group } & \multirow[b]{2}{*}{ Mean } & \multirow[b]{2}{*}{$\begin{array}{l}\text { Std. } \\
\text { Error }\end{array}$} & \multicolumn{2}{|c|}{$95 \%$ Confidence Interval } \\
\hline & & & $\begin{array}{l}\text { Lower } \\
\text { Bound }\end{array}$ & $\begin{array}{l}\text { Upper } \\
\text { Bound }\end{array}$ \\
\hline Experimental & $3.250^{\mathrm{a}}$ & .024 & 3.202 & 3.298 \\
\hline Control & $3.162^{\mathrm{a}}$ & .024 & 3.114 & 3.210 \\
\hline
\end{tabular}

Descriptive statistics are presented in table 5. As displayed in the table, the posttest mean score for the experimental group $(M=3.25)$ on the listening measure is marginally higher than for the control group $(M=3.16)$. This suggests that contrary to expectations, the experimental group experienced more anxiety in comparison to the control group.

Table 6: ANCOVA Results for Experimental and Control Groups on Anxiety Scores

\begin{tabular}{|c|c|c|c|c|c|c|}
\hline & $\begin{array}{c}\text { Type III } \\
\text { Sum of }\end{array}$ & & Mean & & & Partial \\
Eta \\
Source & Squares & df & Square & F & Sig. & Squared \\
\hline $\begin{array}{c}\text { Model } \\
\text { Intercept }\end{array}$ & .042 & 1 & .042 & 3.024 & .089 & .060 \\
\hline $\begin{array}{c}\text { Anxiety } \\
\text { Pretest }\end{array}$ & .742 & 1 & .742 & 53.174 & .000 & .531 \\
\hline Group & .091 & 1 & .091 & 6.554 & .014 & .122 \\
\hline Error & .656 & 47 & .014 & & & \\
\hline Total & 515.312 & 50 & & & & \\
\hline Corrected & 1.407 & 49 & & & & \\
\hline
\end{tabular}

The result of the ANCOVA procedure, $\mathrm{F}_{(1,47)}=6.55$, $\mathrm{p}$ $=0.01$, however, indicated the difference was not statistically significant at the 0.05 level. As a result, the hypothesis to this research question was retained. Promoting learners' TW does not significantly affected the anxiety of the EFL learners. This was further confirmed by the Eta Squared value of 0.122 that indicated a small effects size. As can be seen, the two groups were significantly $\left(\mathrm{F}_{(1,47)}=53.17, \mathrm{p}=0.00\right.$ different at pretest phase; however, the employment of the ANCOVA procedure made it possible to compare the posttest scores while taking the initial difference into account. The within group variability was investigated through Paired Samples.

Table 7: Pretest and Posttest Anxiety Mean Scores for both Groups

\begin{tabular}{|c|c|c|c|c|c|}
\hline \multicolumn{2}{|c|}{} & Mean & $\mathrm{N}$ & $\begin{array}{c}\text { Std. } \\
\text { Deviation }\end{array}$ & $\begin{array}{c}\text { Std. Error } \\
\text { Mean }\end{array}$ \\
\hline $\begin{array}{c}\text { Pair } \\
1\end{array}$ & $\begin{array}{c}\text { Anxiety Ex } \\
\text { Pre }\end{array}$ & 3.1006 & 25 & .17857 & .03571 \\
\cline { 2 - 6 } & $\begin{array}{c}\text { Anxiety Ex } \\
\text { Post }\end{array}$ & 3.1721 & 25 & .13906 & .02781 \\
\hline \multirow{2}{*}{$\begin{array}{c}\text { Pair } \\
2\end{array}$} & $\begin{array}{c}\text { Anxiety } \\
\text { Cont Pre }\end{array}$ & 3.2097 & 25 & .16480 & .03296 \\
\cline { 2 - 6 } & $\begin{array}{c}\text { Anxiety } \\
\text { Cont Post }\end{array}$ & 3.2194 & 25 & .16488 & .03298 \\
\hline
\end{tabular}

As table 7 the pretest and posttest mean scores in both experimental and control groups are very close, suggesting that learners' anxiety was not reduced as a result of promoting their TW. 


\section{International Journal of Advanced Multidisciplinary Scientific Research (IJAMSR) ISSN:2581-4281}

Table 8: Paired T-Test Results Comparing Pretest and Posttest Anxiety Mean Scores.

\begin{tabular}{|c|c|c|c|c|c|c|c|c|c|}
\hline & \multicolumn{5}{|c|}{ Paired Differences } & \multirow[b]{3}{*}{$\mathrm{T}$} & \multirow{3}{*}{\multicolumn{2}{|c|}{$\begin{array}{l}\text { Sig } \\
(2-\end{array}$}} \\
\hline & & \multirow[b]{2}{*}{$\begin{array}{c}\mathrm{Me} \\
\text { an }\end{array}$} & \multirow{2}{*}{$\begin{array}{c}\text { Std. } \\
\text { Devia } \\
\text { tion }\end{array}$} & \multirow{2}{*}{$\begin{array}{c}\text { Std. } \\
\text { Erro } \\
\mathrm{r} \\
\text { Mea } \\
\mathrm{n}\end{array}$} & \multicolumn{2}{|c|}{$\begin{array}{c}95 \% \\
\text { Confiden } \\
\text { ce } \\
\text { Interval } \\
\text { of the } \\
\text { Differenc } \\
\text { e }\end{array}$} & & & \\
\hline & & & & & $\begin{array}{c}\text { Lo } \\
\text { wer }\end{array}$ & $\begin{array}{l}\text { Up } \\
\text { per }\end{array}$ & & & \\
\hline$a$ & $\begin{array}{l}\text { Anxiety } \\
\text { ExPre - } \\
\text { Anxiety } \\
\text { ExPost }\end{array}$ & $\begin{array}{r}- \\
.07 \\
2\end{array}$ & .1657 & .033 & $\begin{array}{r}- \\
.13 \\
92\end{array}$ & $\begin{array}{r}.00 \\
31\end{array}$ & $\begin{array}{r}- \\
2 . \\
15\end{array}$ & $\begin{array}{l}2 \\
4\end{array}$ & .06 \\
\hline$P$ & $\begin{array}{l}\text { AnxietyCo } \\
\text { ntPre - } \\
\text { AnxietyCo } \\
\text { ntPost }\end{array}$ & $\begin{array}{r}.00 \\
0\end{array}$ & .0842 & .016 & $\begin{array}{l}.04 \\
44\end{array}$ & $\begin{array}{r}.02 \\
50\end{array}$ & $\begin{array}{c}.5 \\
7\end{array}$ & $\begin{array}{l}2 \\
4\end{array}$ & .57 \\
\hline
\end{tabular}

Results of the Paired Samples t-test (table 8) further showed that the pretest mean scores were not significantly different from posttest mean scores in both experimental $\left(\mathrm{t}_{(24)}=2.15, \mathrm{p}=0.06\right)$ and control groups $\left(\mathrm{t}_{(24)}=0.57, \mathrm{p}=0.57\right)$.

\section{DISCUSSIONS}

Results for the first research question indicated that promoting learners' TW in the experimental group significantly affected the listening comprehension of the
EFL learners. This finding is in line with that of Tsuchihira (2008) and Yang (2000). Examining the relationships between TW and the English listening comprehension scores, Tsuchihira found a significant relationship between TW and English listening comprehension, suggesting that the participants influences English listening scores. However, judging from the value of the correlation, the score of the testwiseness only explained fifteen percent of the listening comprehension score. Yang (2000) attempted to investigate the influence of TW on performance on the Test of English as a Foreign Language (TOEFL). In order to achieve this objective, 390 Chinese TOEFL candidates were selected and asked to take a TOEFL Practice Test (ETS, 1995d). The results of the thinkaloud protocol analysis showed that test-wise students had higher performance on the TOEFL items. In relation to the second question, it was found that post-treatment anxiety level of the learners in the two groups were not significantly different, suggesting that instructing TW strategies may not reduce learners' anxiety. This finding runs counter to what Vattanapath and Jaiprayoon (1999) have argued. They believe that learning TW helps EFL learners become more relaxed, more confident, and more enthusiastic about taking tests. However, the results of the present study provided support for those of Millman (1966). In Millman's (1966) study no relationship was found between TW and test anxiety.

\section{CONCLUSION}

The first research question inquired whether TW had any significant effect on improving listening comprehension of the Iranian EFL learners. Results for the first research question indicated that promoting learners' TW in the 


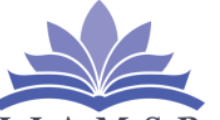

\section{International Journal of Advanced Multidisciplinary Scientific Research (IJAMSR) ISSN:2581-4281}

experimental group significantly affected the listening comprehension of the EFL learners. The second research question inquired whether TW had any effect on foreign language anxiety of the learners; it was found that posttreatment anxiety level of the learners in the two groups were not significantly different, suggesting that instructing TW strategies may not reduce learners' anxiety.

\section{IMPLICATIONS}

These research findings present the following implications for EFL learners, teachers, and curriculum developers in case of dealing with language learning, teaching, and developing EFL materials. Language studies in the domain of teaching test-wises are well advised to take implications presented in this study into thoughtful account. Thus, Language learners should develop their test-wiseness ability in order to improve their foreign language learning process. The area of teaching listening is very important particularly in the present condition of English requirement in Iran where it is taught as a foreign language. Therefore, Iranian EFL teachers should pay special attention to this vital skill in their teaching and enhance their learners' abilities in listening. Consequently, teaching test-wiseness strategies may develop listening comprehension of Iranian EFL learners. Material developers should cooperate with both teachers and students in order to plan and produce suitable listening materials. Cooperating with teachers, they need to decide what teaching materials they might develop to enhance the EFL learners' listening comprehension.

\section{SUGGESTIONS}

Researchers are counseled to consider the following suggestions before carrying out any research.

a) The findings of the current study underline the need for further investigations concerning teaching test-wiseness strategies in the fields of teaching English as foreign/second language.

a) Further research is suggested to use larger samples of both female and male participants to be able to generalize the findings to all EFL learners.

b) Future research needs to spend a longer time than the time spent in this study.

c) Other skills of the language, such as speaking, writing and reading were not investigated. Possibly, applying teaching test-wiseness strategies may be useful to improve other main and sub-skills of the language. Therefore, future research could investigate the effect of teaching, speaking strategies for improving oral and productive skills. 


\section{International Journal of Advanced Multidisciplinary Scientific Research (IJAMSR) ISSN:2581-4281}

\section{REFERENCES}

1) Allan, A. (1992). Development and Validation of a scale to measure test-wiseness in EFL/ESL reading test takers. Language testing, 9, 101-121

2) Bachman, J.(2000). Modern language testing at the turn of the country: assuring that what we count counts. Language testing, 17/1:1-42.

3) Brown, H.D. (2007). Principles of language learning and teaching. San Francisco: Pearson Education.

4) Chance, S.L. (1992).Utilizing test-wiseness to improve test scores in reading for English grade students.Unpublished dissertation.Nova University. South Florida.

5) Chastain, K.(1998). Affective and ability factors in second language acquisition.Language learning.25,153-161.

6) Cohen, A.D. (1998). Strategies in learning and using a second language. Harlow, Essex. Longman

7) Horwitz, E.K, Horwitz, M.B., \&Cope. J. (1986).Foreign language classroom anxiety.The Modern Language Journal, 70(2), 125-132.

8) Millman, J., Bishop, C.H. \&Ebel, R. (1965).An analysis of test- wiseness.Educational and Psychological measurement, 25(1), 700-706.

9) Richards, J.C., Schmidt, R. (2010).Longman dictionary of language teaching and applied linguistic. $\left(4^{\text {th }} . E d\right)$. London: Longman

10) Rogers, T.W. \&Bateson ,D.J. (1991). The Influence of Test-wiseness on Performance of High School Senior on School Leaving Examinations.Applied Measurement in Education, 4(2): 159-183

11) Scovel, T. (1978).The effect of affect on foreign language learning: a review of the anxiety literature. Language Learning Journal, 28(1), 129-142.

12) Vattanapath, $R \quad \& \quad$ K.Jaiprayoon.(1999). An assessment of the effectiveness of teaching testtaking strategies for multiple-choice English reading comprehension tests. Occasional Paper,8,57-71

13) Watter, T.\& Siebert, A.(1990). Students' success, how to successes in college and still have time for your friends. New York: $\mathrm{HOH}$, Rinehart and Winston, Inc.

14) Wenden, A.L.(1991). Learner strategies for learner autonomy.Englewood Cliffs. NJ: Prentice-Hall.

15) Yang, P.(2000). Effects of test-wiseness won performance on the test of English as a foreign language. ( Unpublished Doctoral Thesis). University of Alberta, Edmonton, Alberta, Canada. 